\title{
ФИНЛЯНДИЯ: ОСТАНОВИЛСЯ ЛИ СДВИГ ВПРАВО?
}

\begin{abstract}
Аннотация. В статье рассматривается политическая ситуаџия в Финляндии накануне и после мунищипальных выборов 2017 г. На них три крупнейшие партии страны: Национальная коалиционная партия, Социал-демократическая партия и партия Центра потеряли голоса избирателей, хоть и не очень много. Неожиданной стала существенная потеря поддержки своего электората правой националистической партией «Истинные финны». Вхождение в правительство не пошло этой партийной силе на пользу и сильно обострило противоречия внутри организации, которые вылились летом того же года в её раскол. Образовались две партии: одна - более умеренная осталась в правительстве, другая - радикальная ушла в оппозицию. Прочессы, происходящие в партии, объясняются причинами как внутреннего, так и внешнего характера. Избирателей пугает её радикализм, и происходит отток голосов избирателей в пользу других оппозиционных сил.
\end{abstract}

Ключевые слова: Финляндия, Швеция, муниципальные выборы, правые националистические партии, партия «Истинные финны»

\section{Институт муниципальных выборов в Финляндии}

Тех, кто изучает политику современной Финляндии, пожалуй, более всего интересует внутри- и внешнеполитический вектор развития этой страны. Действительно ли эта страна, с традиционно устойчивой партийно-политической системой и вполне предсказуемой политикой вдруг резко качнулась вправо? Ответить на такой сложный вопрос однозначно очень трудно, можно лишь констатировать некоторые явления внутренней жизни нации, которые при определённых условиях могут выстроиться в устойчивые тренды. Часто симптомами возможных перемен выступают не катастрофические события вроде неожиданного экономического кризиса, резко изменившееся поведение отдельного социального сегмента, выражающегося в бурных акциях протеста, или грандиозный политический скандал. Иногда о возможных серьёзных политических переменах можно судить по какому-нибудь рутинному событию вроде местных выборов.

9 апреля 2017 г. жители Финляндии приняли участие в муниципальных выборах, которые происходят в стране раз в четыре года. На первый взгляд, коммунальные выборы мало о чем говорят. Но не в странах Северной Европы с развитым гражданским обществом, где установлена активно действующая обратная связь между «рядовым избирателем» и представляющим его непосредственные интересы муниципальным советником. По коммунальным выборам можно надёжно судить о политических запросах и настроениях в обществе, особенно интенсивно реализующих себя на местном уровне.

Муниципалитет (коммуна) - административно-территориальная единица местного самоуправления. Всего в стране сейчас 311 коммун. В функции муниципалитетов входит организация дошкольного и школьного образования, медицинского обеспечения, ухода за престарелыми, поддержания в порядке инфраструктуры. Хотя в последнее время в Финляндии,

(C) Плевако Наталия Сергеевна - руководитель Центра Северной Европы, ведущий научный сотрудник Института Европы РАН, кандидат исторических наук. Adpec: РФ, 125009, Москва, ул. Моховая, д. 11, стр. 3.Email: natalia_plevako@mail.ru. DOI: http://dx.doi.org/10.15211/vestnikieran2201814 
как и в других северных странах, усиливается роль частного сектора в предоставлении разнообразных услуг населению, общественный сектор ещё далеко не сдал своих позиций.

То же можно сказать об осуществляемых реформах коммунальной системы. Выравнивание размеров коммун и оптимизация финансирования, сопровождающие процесс их слияния, ведёт к росту бюрократии и ослаблению механизма прямой демократии, которая попрежнему определяет лицо гражданского общества. Финская электоральная система представляет собой комбинацию голосования за кандидата и за партию (за исключением, президентских выборов). При этом на муниципальных выборах существует больше возможности для формирования кратковременных избирательных союзов, поскольку кандидатов могут выдвигать как зарегистрированные партии, так и избиратели, специально создавшие избирательное объединение. Участвовать в муниципальных выборах и быть избранными (в отличие от парламентских, где голосуют только граждане страны) имеют право приезжие жители, если они находились в стране на законных основаниях не менее двух лет.

В местных выборах 2017 г. участвовало 58,9\% жителей страны - чуть больше (на 0,6\%), чем на предыдущих коммунальных выборах 2012 г. ${ }^{1}$ Разброс цифр электоральной активности между различными коммунами - велик: от 49,3\% до 82,6\%, причём это не всегда зависит от величины коммуны. Хотя электоральная активность в Финляндии выше, чем во многих других странах Европы, финские политики и обществоведы считают её недостаточной и обсуждают вопрос, как сделать местные выборы более привлекательными для избирателей. Предлагают, в частности, проводить все выборы в один день, как в соседней Швеции, выбирать губернаторов прямым голосованием, разрешить голосование по интернету, снизить возрастной ценз.

Победу на выборах одержала Национальная коалиционная партия, набравшая 20,7\% голосов (-1,2\% по сравнению с предыдущими выборами), второй партией стала Социалдемократическая партия Финляндии - 19,4\% (-0,2\%), третье место заняла партия Центра самая большая по численности $-17,5 \%$ голосов $(-1,1 \%)^{2}$. Таким образом, все три крупнейшие партии потеряли, хотя и незначительно, голоса избирателей.

\section{Правые националисты отступают?}

Главной неожиданностью стало серьёзное отступление правой националистической партии «Истинные финны», политический вес которой ещё недавно постоянно возрастал. В 2007 г. её поддерживало всего 7\% избирателей, но уже на парламентских выборах 2011 г. она набрала 19\% голосов. Электоральный успех был подтверждён и на парламентских выборах 2015 г., хотя процент голосовавших за неё тогда немного снизился (до 17,7\%). «Истинные

\footnotetext{
$1 \ldots$ Available at: https://vaalit.yle.fi/resultat/kv2017 (Accessed: 30 April 2018). ${ }^{2}$ ibid
} 
финны» оказались второй по числу депутатов в финском парламенте партией, получив в правительстве пять министерских портфелей высокого значения, в частности, министра иностранных дел (Т. Сойни) и министра обороны (Ю. Ниинистё). Объяснением феномена такого успеха партии в начале второго десятилетия 2000 гг. можно считать два основных фактора: высокая безработица как в сельскохозяйственных, так и индустриальных районах (порядка $13 \%{ }^{1}$ ); влияние экономического кризиса на уровень потребления рядовых граждан (значительная часть избирателей, голосующих за эту партию, - низкооплачиваемые слои населения). Сами «Истинные финны» позиционируют себя как партию трудящегося народа, партию «маленького человека», защиту интересов которого они отождествляют с защитой национального интереса. А эта защита, как они утверждают, находится в противоречии с проводимой традиционными политическими партиями иммиграционной политикой. Такая постановка вопроса способствовала переходу к ним части электората от социал-демократов, недовольство политикой которых росло пропорционально ухудшению экономической ситуации. Одним из ключевых вопросов, выдвинутых этой партией (наряду с мерами по ликвидации последствий экономической депрессии и политикой по отношению к ЕС), стала ситуация с иммиграцией в Финляндию. В программе партии (2015 г.) декларируется, что «Финляндия должна освободиться от прокламируемой уже в течение 25 лет мысли о мультикультурализме как основополагающей идеи иммиграционной политики». ${ }^{2}$ «истинные финны» выступают за сокращение иммиграции в страну, особенно нетрудовой, настаивают на ускорении адаптации и интеграции иностранцев, сокращении для них льгот и выплат, особенно для тех категорий, которые имеют целью сохранение своей культуры в неизменном виде. Для партии мультикультурализм теряет сколько-нибудь положительный смысл. По мнению её идеологов, адаптация должна вести к ассимиляции, как наиболее приемлемой форме интеграции.

И вот - выборы в муниципальные органы власти 2017 года приносят поразительные результаты. «Истинные финны» собирают всего 8,8\% голосов избирателей $(-3,5 \%)$, то есть опускаются почти до уровня десятилетней давности, когда с ней особенно не считались.

Почему же произошло такое падение? Пребывание у власти, особенно, когда речь идёт об участии в коалиционном правительстве, всегда является испытанием для любой партии. Накапливаются противоречия в партийных рядах, особенно, когда речь заходит о поддержке или неприятии политических инициатив, исходящих от партнёров по правительственной коалиции. А это, в свою очередь, оказывает влияние на целостность партии. Такая судьба не обошла стороной и «Истинных финнов». После успеха на парламентских выборах 2011 г. они стали третьей политической силой в стране и приступили к переговорам о вхождении их членов в правительственную коалицию. Однако переговорный процесс был прерван из-за разногласий по вопросу об экономической помощи Португалии - по этому вопросу «Истин-

1 ....Available at: https://tilastokeskus.fi/til/kvaa/2012/kvaa_2012_2012-11-02_tie_001_sv.html (Accessed: 29 April 2018).

${ }^{2}$ Sannfinländarnas Invandringspolitiska Program (2015). Available at: http://www.perussuomalaiset.fi/wp-content/ uploads/2014/04/ps_invandringspolitiska_2015.pdf (Accessed: 30 April 2018). 
ные финны» выступали достаточно сплочённой силой. Ещё больший успех на парламентских выборах 2015 г. этого, как тогда казалось, политического монолита, вынудил премьерминистра Ю. Сипиля заключить с партией соглашение о вхождении в коалиционное правительство. Однако, оказавшись министром иностранных дел, основатель «Истинных финнов» T. Сойни был вынужден еx oficio участвовать в принятии решений и реализации таких болезненных проектов, как оказание финансовой помощи Греции в условиях тяжёлого экономического положения в самой Финляндии, а также приём растущего числа беженцев и иммигрантов. Это, естественно, вызывало недовольство тех членов партии, которые изначально были настроены более радикально, квалифицируя подобную политику несовместимой с основополагающими принципами партии, и считая, что «Истинные финны» теряют своё лицо. Турбулентность в партии, продолжавшаяся после неудачных для неё муниципальных выборов, в конце концов на съезде в июне 2017 г. привела к расколу её партийных рядов. Борьба за пост председателя шла между С. Терхо - сторонником Т. Сойни и Ю. Халла-ахо - членом Европарламента, специалистом по старославянскому языку, националистом-интеллектуалом, который дважды был осуждён за разжигание межнациональной розни и оскорбление чувств верующих. С большим преимуществом победил Ю. Халла-ахо (соотношение голосов 941:629). Он привёл с собой команду сторонников, которые отличались от бывшей команды Т. Сойни агрессивностью, настойчивостью в осуществлении курса на максимальное ограничение иммиграции и евроскептицизмом. В ответ на победу радикалов 20 парламентариев от «Истинных финнов», включая Т. Сойни, создали свою фракцию под названием «Новая альтернатива», которая впоследствии превратилась в партию «Синее будущее». В эту фракцию, руководителем которой стал С. Эло, вошли и действующие министры, заявившие о своей готовности продолжать работать в правительстве. Фактически это спасло правительство, которое готово было уйти в отставку из-за несогласия с линией нового руководства «Истинных финнов» и нежелания работать с ним.

Ещё до раскола политические обозреватели отмечали, что результаты парламентских выборов 2015 г., вероятно, являются пределом возможностей этой правонационалистической партии (на муниципальных выборах 2012 г. за неё проголосовало 12,3 \%, а на выборах в Европарламент - 12,9\% избирателей). Но потери на последних выборах правых националистов многие объясняют не только внутрипартийными процессами. У них забирают голоса и партии, которые рядовые, недовольные, но неискушённые избиратели рассматривают как более спокойный вариант противостояния правительственному курсу. В этом заключается объяснение высокого электорального результата партии «Зеленых» - 12,5\% (+3,9\%), набравшей больше голосов, чем «Истинные финны». Большой успех сопутствовал этой партии в столице Финляндии, где она получила $24,1 \%{ }^{1}$, почти догнав Национальную коалиционную партию. В. Ниинистё, руководитель партии, племянник президента страны заявил после выборов, что «Зелёные» вышли на новый уровень благодаря успеху на местных

\footnotetext{
${ }^{1}$ Niinistö: Greens on new level after election success. Available at: http://www.helsinkitimes.fi/finland/finlandnews/domestic/14680-niinistoe-green-league-on-a-new-level-after-successful-municipal-elections.html (Accessed: 29 April 2018).
} 
$\operatorname{pax}^{1}$. Программа финских «зелёных» мало чем отличается от программ подобных европейских партий. Они позиционируют себя как открытую, неиерархическую организацию, отказываясь в применении к себе понятий «левая»-«правая» партия на политической шкале 2 . Да, социальная опора у «Зелёных» и «Истинных финнов» кардинально различается. Первые пользуются в основном поддержкой интеллигенции, вторые апеллируют к низшим классам. Но их роднит критическая позиция к существующей власти, что допускает некоторый перелив голосов избирателей от одной партии к другой в зависимости от изменений политической ситуации в стране.

Значительные разногласия в право-популистских партиях между умеренными членами, которые готовы идти на сотрудничество с партиями истеблишмента и радикальными элементами, характерны не только для Финляндии. Раскол подобного рода случился в марте 2018 г. и в партии «Шведские демократы», хотя она никогда и не участвовала в правительственной деятельности. Радикальное молодёжное крыло партии, многие члены которого были исключены из её рядов, дабы придать ей более «благопристойный» вид, требовало от руководства более профилированной иммиграционной политики: организации возвращения иммигрантов на родину, прекращения экономической помощи нуждающимся странам. В области экономической политики они также шли дальше руководства, выступая с несостоятельными требованиями отмены прогрессивного налогообложения и превращения экономики страны в самообеспечивающуюся систему.

В конечном счёте, можно констатировать, что правонационалистическое движение в Финляндии (что характерно и для других стран Северной Европы) прошло пик своего развития и начинает сдавать позиции. Однако, несмотря на дробление и конкуренцию со стороны иных оппозиционных сил (левые, «зелёные»), оно остаётся весьма заметным фактором политической жизни страны. Будущее правых националистов зависит не только от ситуации в самой Финляндии, но и в не меньшей степени от того, справятся ли страны Евросоюза с новыми и старыми вызовами: миграционные волны, симптомы возникновения «торговых войн», участие или неучастие в инициативах, нередко весьма рискованных, предпринимаемых Соединёнными Штатами Америки.

\section{Список литературы}

Юссила О., Хентиля С., Невакиви Ю (2010) Политическая история Финляндии 1809 2009 = Osmo Jussila, Seppo Hentilä, Jukka Nevakivi. Suomen poliittinen historia, 1809-2009 / Пер. с финск. - М. : Издательство «Весь Мир».

Коваленко Н.Е. (2008) Местное самоуправление как форма демократии. Спб.

Могунова М.А.(2005) Государственное право Финляндии. Городец.

\section{References}

\footnotetext{
${ }^{1}$ ibid

2 ....Available at: http://www.vihreat.fi/files/liitto/Greens_principle_programme.pdf (Accessed: 30 April 2018). Научно-аналитический вестник ИЕ РАН, 2018, №2
} 
Osmo Jussila, Seppo Hentilä, Jukka Nevakivi (2010) "Politicheskaya istoria Finlandii, 18092009" (Political history of Finland). Moscow.

Kovalenko N.E. (2008) "Mestnoe samoupravlenije kak forma demokratii" (Local government as a form of democracy).St. Petersburg.

Mogunova M.A. (2005) "Gosudarstvennoje pravo Finlandii" (State law in Finland). Gorodets.

\section{Finland: Has the Shift to the Right Stopped?}

Author. Plevako N., PhD (History), Head of the Centre for Northern Europe Studies, Leading Research Associate, the Institute of Europe, Russian Academy of Sciences. Address: 11-3, Mokhovaya street, Moscow, Russian Federation, 125009. E-mail: natalia_plevako@mail.ru.

Abstract. The article deals with the political situation in Finland before and after the municipal elections 2017. The three largest parties of the country: the National Coalition Party, the Social Democratic Party and the Center party have lost, though not very much, the votes of the electorate. Unexpected was the retreat of the right-wing nationalist party The Finns, who lost $3.5 \%$ of the vote. Entering the government did not benefit this party and greatly exacerbated the contradictions within the organization, which led to the split of the party in the summer 2017.Two parties were formed: the party, which is more moderate remained in the government, but the radical one went into opposition. The processes taking place in the party are explained by the reasons of both internal and external nature. Voters are frightened by its radicalism and there is an outflow of their votes in favor of other opposition parties.

Keywords: Finland, Sweden, municipal elections, right-wing nationalist parties, The Finns party.

DOI: http://dx.doi.org/10.15211/vestnikieran2201814 